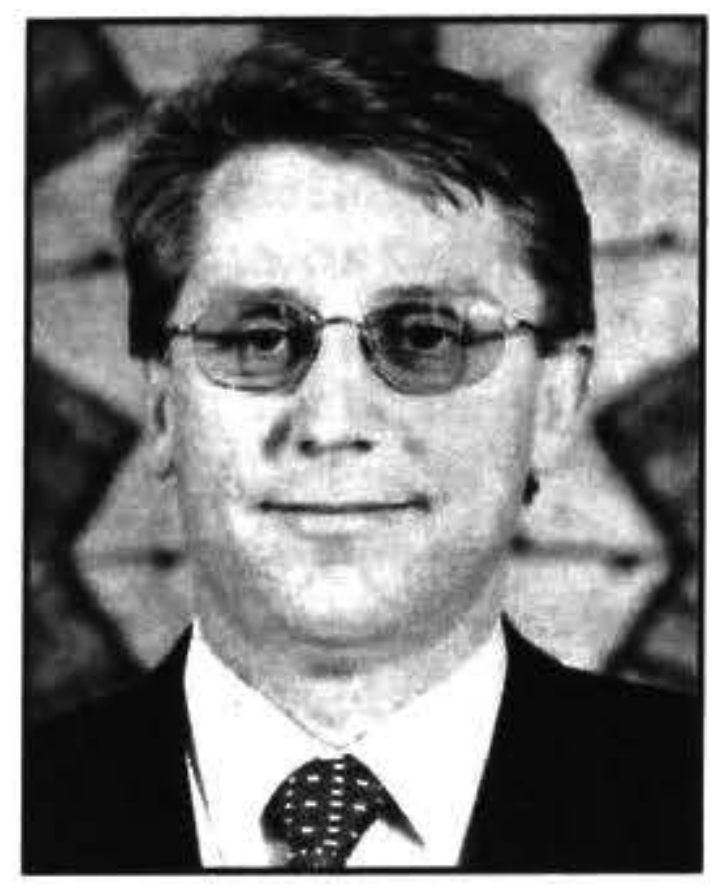

\title{
CULTIVATING CULTURE IN GREENFIELDS: THE HEINZ WATTIE'S CASE
}

\author{
Paul Hursthouse \\ Faculty of Business Studies \\ Eastern Institute of Technology
}

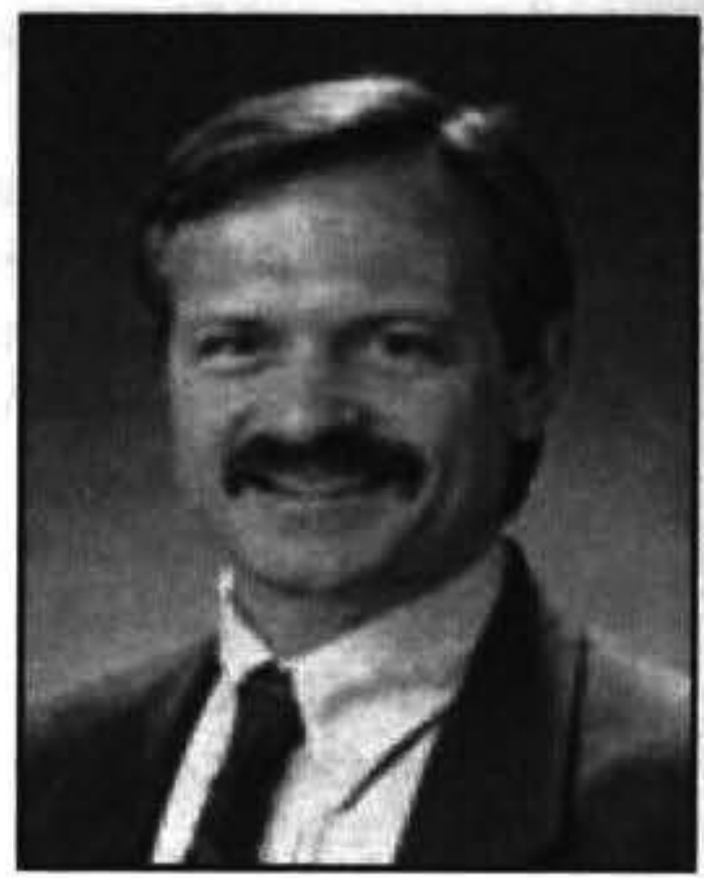

\section{Darl Kolb}

\author{
School of Business and Economics \\ University of Auckland
}

\begin{abstract}
The establishment of new plants in Greenfield sites is a strategic organisational initiative providing the opportunity to develop alternative systems of staff values and beliefs which may be more appropriate for capitalising on external product market opportunities. This paper explores whether an alternative organisational culture can be established at a Greenfield site within a New Zealand food processing plant. This case organisation utilised the provisions of the Emplovment Contracts Act 1991 to establish alternative employment conditions in the Greenfield site to those of its Brownfield site. A comparative analysis was made utilising quantitative organisational culture data from Human Synergistic's Organisation Culture Inventory. The data reveals the similarities and differences between the Greenfield and Brownfield sites and provides the basis for discussion of whether culture can be managed through the mechanism of a Greenfield site. Critical elements in creating a desired culture are identified.
\end{abstract}

Keywords: Greenfield and Brownfield sites, Organisational Culture

This paper, describes part of a larger study which investigated whether an alternative organisational culture could be established in a Greenfield site within the same organisation (Hursthouse, 1999), and continues the author's earlier interest in examining strategic choice through alternative enterprise bargaining arrangements (McAndrew and Hursthouse, 1990). The present paper provides an overview on whether the establishment of a Greenfield site has developed an 'organisational culture' which is different from that found within a Brownfield site and seeks to provide some explanation of why any differences may occur.

The case study organisation that provides the platform for the research is the Hastings, New Zealand, plants of Heinz Wattie's Australasia. The Hastings operation has two plants, King Street which has its roots dating back to 1934 and over time established Wattie's as an icon of New Zealand business, and is the Brownfield site examined in this research. The second plant is Tomoana which was a Greenfield site opened in 1996. Both are food processing plants and contribute positively to the corporate goals of Heinz International.

This case is considered in the wider context of organisations needing to respond quickly to the rapidly changing demands of the market place to achieve a competitive ad- vantage. The strategic initiative of organisations establishing Greenfield sites provides them with the opportunity to establish plants with alternative systems that may implicitly or explicitly result in staff having an alternative set of values and beliefs to those of the other more established plants. These new values and beliefs may be more appropriate for capitalising on external product market opportunities.

\section{Competitive Advantage and Greenfield Sites}

There have been a number of studies to determine the relationship between product markets and employee relations (Batstone et al., 1984, Cappelli, 1985, Goodman et al., 1977, Gospel and Littler, 1983, Kochan et al., 1985, Marchington and Loveridge, 1983, Purcell and Grey, 1986.). The underlying theme throughout these studies is that the degree of competitive pressure the company, or business units within the company, experiences in the market can have a dramatic effect on employee relations. As competitive pressure increases, employers will attempt to achieve competitive advantage over their rivals by exploring alternative ways to increase the effectiveness of the labour process (Marchington, 1990). One way to achieve this is by establishing a Greenfield site. 
The concept of "Greenfield" sites originated from the United States in the early 1980 's when industrial relations researchers investigated a developing trend of organisations that established production facilities in totally new locations (Guest and Rosenthal, 1993). The managers of these organisations were starting to exercise a degree of "strategic choice" on where to locate production facilities. Such new sites would enable managers to develop alternative Human Resource strategies from that of the "old and established" plants with a view to gaining some form of competitive advantage.

Initially within the USA, the vehicle to achieve this competitive advantage came in the form of carefully selecting the location of sites so that there would be a suitable nonunion workforce (Foulkes, 1980). By implication it was felt that a unionised plant inhibited management's ability to manage and that Greenfield sites would provide management with an opportunity to start afresh, unbound by any constraints of the past. Yet the constraint of union activity was not the sole motivation for establishing Greenfield plants. Indeed "it was believed that the range of management practices associated with HRM as a separate and distinct approach to the management of people could most easily and successfully be introduced by companies establishing themselves on Greenfield sites" (Leopold and Hallier, 1997, p. 72).

\section{The New Zealand Context}

Until the 1980's, New Zealand industries were protected by government tariffs which sustained a broad and relatively inefficient, but insulated manufacturing sector. Labour costs and productivity were not critical to their viability because employers in the manufacturing sector operated comfortably in a cost plus environment. By the mid-1980's new levels of global competition were emerging and at the same time Britain's accession to the European Economic Community ravaged New Zealand's reliable markets for export agricultural products. These developments generated widespread pressure to reduce the costs of production and to increase productivity, including labour productivity, throughout the economy. Lobbyists argued that under these unprecedented economic pressures, New Zealand's labour relations'system was inadequate as it was not conducive to competitiveness internationally or domestically (New Zealand Business Roundtable, 1989).

There was a change in government in 1990 and when the conservative National Government took over the helm they immediately instigated labour market reform. The result was the enactment of the Employment Contracts Act 1991 which some have described as the most radical industrial relations reform in New Zealand for over 100 years. This provided businesses with the opportunity to change various Human Resource Management practices. In particular it provided business with the opportunity to change their "industrial agreements" from predominantly national, predominantly occupational, award based structures to a company wide, site by site, department by department or ultimately, individual by individual basis.

The establishment of a Greenfield site would provide greater scope for capitalising on the options available within the new legislative environment, free from the constraints of existing industrial agreements. However unlike the antiunion motivation displayed by many USA businesses for the establishment of Greenfield sites, the motivation could have been more consistent with Clark's (1995) suggestion that Greenfield sites provide 'opportunity structures for innovation, experiment and new philosophies' to encourage such things as multiskilling, worker participation and innovation.

Clearly the literature suggests that there are good strategic Human Resource reasons for establishing a Greenfield site (Leopold \& Hallier 1997, Guest \& Rosenthal 1993, Preece 1993). For example in the USA the focus appears to be antiunion, in the UK and Australia it is introducing human resource practices so that there is single union recognition, and perhaps in New Zealand it could be innovation in human resource strategies and operations management techniques. While the notion of introducing new management philosophies appears in the Greenfield literature, there is limited explicit reference to establishing a Greenfield site with the purpose of developing an alternative culture and using this alternative culture to introduce competitive business practices.

Organisational culture has many and varied definitions. Kroeber \& Kluckhohn (1952) cited in (Frost et al., 1985 , p. 75) suggested that in 1952 there were as many as 164 meanings of the term 'culture' that had been used in anthropology and other fields e.g (Crane, 1994). Since then it could be hoped that the field may have been further refined and a more 'common' definition may have been agreed to. Instead, what culture is and the nature of it is still hotly contested (Bolman and Deal, 1991). However for the purposes of this discussion it is proposed to use the definition of one of the more prominent writers on organisation culture. Schein, (1992) defined organisational culture as:
A pattern of shared basic assumptions that the group learned as it solved its problems of external adaptation and internal integra- tion, that has worked well enough to be considered by members as the correct way to perceive, think and feel in relation to those problems.

The question of whether culture can be managed also divides theorists. Schein, (1992), Peters and Waterman, (1982) and Pettigrew, (1979) support the proposition while Per-Olof Berg cited in (Frost et al., 1985, p. 298) and Gagliardi, (1986), Krefting and Frost, (1985) expound a contrary view. The case study used for the research provides an opportunity to test the proposition and identify some elements of managing culture. 


\section{The Heinz Wattie's Case}

To examine the notion of organisational culture and Greenfield sites an intensive study was conducted of the two Heinz Wattie's Australasia, Hastings, New Zealand plants. In 1934, the company founder, Sir James Wattie had the vision and determination to establish a food processing company located on the East Coast of New Zealand's North Island. Today it is a base for one of the world's leading food manufacturing companies, Heinz Wattie's Australasia.

Over the years Sir James Wattie earned a reputation for knowing and looking after his staff. "His door was always open. You could go up the stairs and see him anytime about anything. You could always see him - his door was open to staff"' (Conly, 1984, p. 137). A national daily New Zealand newspaper, the Dominion reported that "His genuine personal interest in those working for him, his humility and friendliness towards his people as he moved around the plant, and his constant endeavour to understand the personal problems of his employees, created an industrial climate which gave his plant a record of industrial harmony second to none" (Conly, 1984, p. 133). Although Sir James Wattie died in 1974 his legacy and philosophies were carried on by his two sons, Gordon and Raymond. 'The values and culture of Wattie's in the seventies was strong and unified and totally in agreement with the founders' ideas' (Irving and Inkson, 1998, p. 27).

Consistent with the changes being experienced throughout the economy, the 1980's also saw many changes for Wattie's. Ray and Gordon Wattie retired from the company, new levels of competition were being felt from a market that was becoming more and more deregulated, new managers felt the need to merge with other businesses and restructure those that remained, and redundancies were being experienced by Sir James's once loyal staff. Then in 1987 Wattie's merged with Goodman Fielder to become the Goodman Fielder Wattie Group, with headquarters in Australia. Wattie Industries was split into a series of smaller companies. In 1992, just five years after it's initial purchase, Goodman Fielder Wattie decided to sell the New Zealand Business units to Heinz.

\section{Team Tomoana - The Greenfield Site}

The closure in August 1995 of the Tomoana Freezing Works located three kilometres from the existing King Street plant provided Heinz with an opportunity for further local development. On $8^{\text {th }}$ December 1995 Heinz announced the purchase of the Tomoana Freezing works with the intention of converting it to a food processing facility. It provided Heinz with the opportunity to double their potential production capacity. Almost immediately Heinz Wattie's embarked on a significant programme of expansion and investment at the Tomoana site.

A senior manager at the King Street (Brownfield) site felt that the Tomoana (Greenfield) site provided the company with an excellent opportunity to trial alternative management practices to those currently being adopted within the Brownfield site. He initiated a meeting with the General Manager and Human Resource Manager and said:

\begin{abstract}
Hey we can't miss this opportunity, we are not going to get another Greenfield site again, they come along once in about 50 years in most organisations - so we have to agree as a group on how best to take advantage of this opportunity and how best we can get the staff involved in managing the business.
\end{abstract}

At the meeting it was agreed that although they were going to manage both sites from King Street, they would manage them in a totally different way. They made a conscious decision to manage and run the Tomoana plant differently. 'The management style and cultural style was going to be our centre of excellence' (Site Management, 1999).

To achieve this outcome the three managers developed a set of principles by which the company would operate. The principles were then used as the basis for developing the structure of a proposed new employment contract to be offered to new staff. Instead of having to negotiate incremental change to the existing employment contract at the Brownfield site, the company could take advantage of New Zealand's radically changed industrial relations system and in particular the provisions of the Employment Contracts Act 1991. At the new Tomoana (Greenfield) site the Employment Contracts Act allowed management to create a new set of employment practices for the new employees unbound by those applying at the King Street site.

The King Street (Brownfield) site contract was primarily a 'classification' based industrial document with remuneration being linked to how long employees had been in their position and what job they were doing. Indeed, an analysis of the 146 page Employment Contract shows a total of 110 job classifications. It is an extremely detailed, comprehensive and very prescriptive Collective Employment Contract. The industrial document covering the Tomoana (Greenfield) site was deliberately different not only in content but in its 23-page length. In fact the original employment contract was so different it was described by management as 'not really an employment contract, it was more a philosophical document of intent'. The foundations were a promise from management for employee participation in decision making and "earning through learning."

The Tomoana (Greenfield) site's contract terms and conditions reinforced the Team Philosophies, for example through flexible sick leave, skill based pay, operation of an hours bank, which are distinctly different from the very prescriptive King Street terms. Another difference has also been the degree of union coverage with approximately $50 \%$ of the staff electing to enter the collective contract under their own bargaining authority. The remaining staff have 
elected to seek the services of union bargaining agents. This compares with approximately $87 \%$ of the King Street staff remaining with union coverage. To this day the unions have no party status to the Tomoana contract.

In addition to the changed contractual arrangements, the company also adopted alternative recruitment and selection techniques to those of the Brownfield site. They started from scratch and carefully selected staff who met a predetermined and rigorous criteria.

\begin{abstract}
We decided to run Tomoana in small teams of manufacturing units - not all that different from King Street operation, just more self-sufficient. We advertised for 'Team Tomoana' specifically because we wanted team people. Fifteen people were recruited for the jam line. These people are being trained to turn their hand to any job required in jam production - from cleaning to driving a forklift. This is the flexible culture we will have throughout Tomoana that will ultimately lead to increased performance (Phil Thirkell , Operations Manager quoted in Singer, 1996, p. 21).
\end{abstract}

This process was viewed as so pivotal that senior management were also involved in the selection process including the Manufacturing Manager.

I interviewed all of those new staff personally myself and the attributes we were looking for were people who could work in teams and people who had a higher than normal level of maths and language skills than would normally be expected in the food processing industry.

The concept of teams and flexibility of deployment was going to be a core attribute of the new plant.

\begin{abstract}
At King Street the culture is traditional, and slow to change to autonomous work teams. If you were to walk around the King Street plant you would see only certain people driving forklifts or checking quality. That doesn't happen at Tomoana. In the team situation it is the team itself which decides who performs what role. When the person putting the jars on the conveyor belt runs out of jars it is not a case of having to find a forklift driver to get more jars - the same person can go do it... we knew if we could get the right mix of people at the start, then everything else would be easier to teach (Karen Scott, Human Resources Manager quoted in Singer, 1996, p. 36).
\end{abstract}

The theme of valuing people and emphasising the team approach is followed through from the contract to the staff handbook.
You will find the environment at Tomoana has more freedom and is more challenging than conventional workplaces. It is the differences in style and philosophy that set Team Tomoana apart. Providing an atmosphere in which team work can flourish are the key foundations of partnership which are at the very heart of the culture' (Heinz Wattie's, 1998, p. 5).

Local management implemented a deliberate and overt strategy to create a new culture at Tomoana. Led by the Operations Manager, they are utterly committed to the values and trust that are the foundations of the Team Tomoana Concept. 'I've got a passion for it and I've got managers out there with a passion for it.' In their view, however, the multinational owners are cynical about the Tomoana experiment, however 'because Heinz is resultsorientated and how you get there is not questioned if you achieve the bottom line result' (Site Management, 1999), local management will be free to continue with the experiment of alternative management and employment practices at the Tomoana site as long as the site does achieve the targets set, which it has to date. Whether these deliberate management strategies have resulted in the divergence of an organisational culture between the Greenfield and Brownfield site is tested in this study.

\section{Research Methodology}

Just as it is difficult to define culture, there is considerable disagreement over the appropriate method(s) with which to investigate it. By far the most pervasive method of cultural inquiry is ethnographic and other qualitative case study techniques (Ott, 1989; Siehl \& Martin, 1988). While the strength of these methods is undisputed, according to Siehl and Martin, the 'advantages of qualitative methods have been bought at a cost.' The copious quantities of data and subsequent in-depth analysis, while informative to academic audiences, often has little utility for practicing managers or other organisational members. Pointing out the interest in culture by non-academics, Alvesson and Berg (1992) have suggested that culture research, in many cases, should attempt to be not only rigorous, but also accessible for interpretation by managers, as well as academics. To this end, quantitative methods are often more easily understood and useful for organisations undergoing change or attempting to understand and, to the extent possible, manage their organisation's culture.

In the case of Watties, an organisatonal culture audit tool, the 'Organisational Culture Inventory' or 'OCI (c) had been adopted by the company as a way for managers to assess dimensions of their organisation as part of a larger, ongoing organisational development exercise. The OCI @ is a 96-item, Likert-type scaled questionnaire, developed by Cooke and Lafferty (1983), to 'assess the ways in which organisational members are expected to think and behave in relation to both their tasks and to other people' (Cooke and Rousseau, 1988, p. 252). The Inventory has high in- 
ternal reliability (Xenikou and Furnham, 1996) and is one of the more frequently used culture tools in New Zealand.

The $\mathrm{OCI}$ (c) can be categorised into three general types of organisational cultures, 'Constructive', 'Passive-Defensive', and 'Aggressive-Defensive'. A description of each of these cultural styles is as follows:

\section{Constructive cultures, in which members are encouraged to interact with others and approach tasks in ways that will help them meet their higher-order satisfaction needs, are characterised by Achievement, Self ac- tualising, Humanistic-Encouraging, and Affiliative norms.}

\section{Passive/Defensive cultures, in which mem- bers believe they must interact with people in wavs that will not threaten their own se- curity are characterised by Approval, Con- ventional, Dependent and Avoidance norms ; and}

\begin{abstract}
AggressivelDefensive cultures in which members are expected to approach tasks in forceful ways to protect their status and security, are characterised by Oppositional. Power, Competitive, and Perfectionistic norms' (Cooke and Szumal, 1993, p. 102).
\end{abstract}

In using the instrument, Wattie's elected to sample all staff, both management and operational staff, working within both the Tomoana and King Street sites. This decision meant that the survey was completed by 43 staff at the Tomoana site and 452 staff at the King Street site. The company developed a timetable to enable all staff to complete this exercise over a two week period in August 1997. Staff were assured that responses would remain confidential.

In order to protect against the possibility that responses could be traced back to any individual respondent, there was an agreement reached between Wattie's and the researcher that data groupings of less than 6 people would not be evaluated. They could form part of the aggregate data set but could not in themselves be analysed further. This, of course, was problematic in that managers at the greenfield site fell into this exclusion. While some greenfield/brownfield comparisons are possible, unfortunately, many were unavoidably hampered due to this restriction in the data analysis. Moreover, since the OCI @ is a commercial product, the local provider denied access to the full data set. Averaged raw scores for each site on each $\mathrm{OCI} \odot$ dimension were provided for our secondary analysis. Data provided were compared across sites using a parametric, one-tailed t-test. Each hypothesis was examined at the 0.05 significance level to accept or reject the null hypothesis.

\section{Findings}

The results from each site were aggregated to determine whether there was, overall, a difference between the Brownfield and Greenfield sites. The difference between the average score of 2.89 for the Brownfield site and 2.77 for the Greenfield site statistically significant different at the .01 level. This result indicates that the cultures of the sites are different, in terms of those constructs measured by the OCI (c) instrument. A breakdown of the OCI (c) 'Norms' and 'Styles' of culture are found in Table 1.

The cultural styles, Constructive, Passive-Defensive, and Aggressive-Defensive, are each supported by 32 questions on the OCI @. When the average score for each of these questions and combined (averaged) averages of these items were compared, the t-test results indicate that the difference between the Constructive, Passive-Defensive cultural styles of the Greenfield and Brownfield sites were statistically significant at the .05 level. It must be noted, however, that, for the cultural style, Constructive, the norms of 'Achievement', 'Self-actualising' and 'Affiliative' were not significantly different between sites, but the ratings of the norm, 'Humanistic-Encouraging', were so high that they statistically pulled the differences between the sites to a level of significance.

All of the eight cultural norms that made up both the Passive-Defensive and Aggressive-Defensive were found to have a statistically significant difference between the Greenfield and Brownfield sites. The results show that there is a clear difference between the culture of the Brownfield and Greenfield sites. In particular, nine of the twelve OCI @ cultural "Norms" and all three of the aggregated cultural 'Styles' show a statistically significant difference.

In summary, in the Heinz Wattie's case, according to these OCI (c) results, the organisation's attempt to manage the two plants differently has resulted in a different culture being established in the Greenfield site, lending credence to the proposition that an organisation's culture can be managed through the establishment of a Greenfield site.

\section{Discussion}

An instrument like the Organisational Culture Inventory (OCI @ ) cannot fully portray the rich subtleties of an organisation's culture and, indeed, it provides only a superficial snapshot of the myriad complexities of either 'old' established or 'new' managed/created cultures. Nevertheless, if we accept that multiple items measured across a Brownfield and a Greenfield site might serve as an indicator or differences, then we have to recognise that there was something different about the newly created culture of Heinz Wattie's Tomoana.

Heinz Wattie's adopted an approach which reflected international experience, and sought ways of gaining a strategic advantage from the industrial relations environment. 
Table 1. Summary of Average Scores Brownfield versus Greenfield

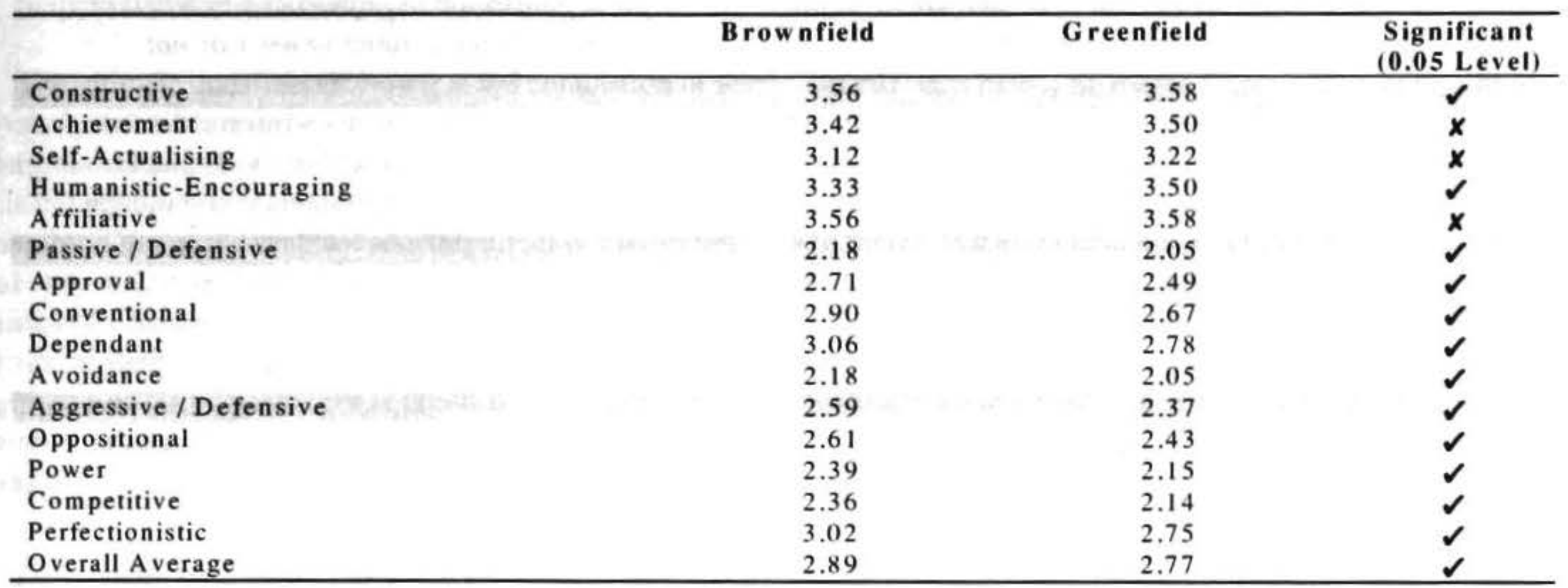

The provisions of the Employment Contracts Act 1991 allowed the company to establish a new set of employment terms and conditions at the Greenfield site. They had the freedom to experiment with new philosophies and potentially use these philosophies as a catalyst for change. Starting anew and having the ability to negotiate terms and conditions that the new management felt were appropriate was an opportunity that the Greenfield site and the changed Industrial Relations system offered to create a 'designer' culture (Casey, 1999).

The perceived weakness of the Brownfield employment terms and conditions contained in the industrial document that is based on classification, years of service, rules and third party interference were able to be addressed. Management had the opportunity to start with a blank page and negotiate an industrial document that was based on payment for competency not years of service, and on trust. not rules and regulation. The Greenfield site was established with employment practices based on the underlying philosophies of 'earning through learning' and a promise to participate in decision making. This was the Greenfield Team Tomoana Concept and management's hope was that the new employment practices would support a different organisational culture.

Management ultimately controlled who worked and did not work for this new organisation by implementing rigorous recruitment and selection strategies. People were carefully selected against predefined criteria. Management proactively managed the new site and did not just let it evolve. It was going to be different. The site was going to be used as a vehicle for change and management intended to use it to break the shackles of the past. Local management were determined that the vehicle had to be built to the right, yet different specifications. This is consistent with key aspects of Baird's (1999) work in progress wherein she defines Greenfields as 'breaking free of past constraints and introducing new arrangements associated with technology, work, management and labour practices.' The attempt by the case study organisation to manage and shape the Greenfield site towards a new and different culture appears from the results to have been achieved with nine of the twelve cultural norms recording a difference.
It is interesting to compare how this different culture was formed, to the process by which Schein (1992) believes that cultures are formed. There is similarity with the first of Schein's suggested sources of culture which is the beliefs, values and assumptions of the founders, as in the case study the architects of the Greenfield site were indeed key managers from the Brownfield site. These key architects then deliberately went out and recruited new leaders for the Greenfield site. Secondly, although the recruitment and selection processes could potentially attract new leaders who had similar beliefs, values and assumptions to the key Brownfield architects, nonetheless the beliefs, values and assumptions of these people would still be new to the Greenfield site. Finally, as the new group members learnt from interacting with their internal environment at the Greenfield site they developed and grew with the new organisation which contributed to the organisational culture. This is consistent with Schein's third proposition, namely that the learning experiences of group members as their organisation evolves, contribute to the development of culture.

On the face of the Brownfield versus Greenfield findings one could perhaps superficially discard Schein's (1992) unitary organisational culture concept. However these findings could also be consistent with his proposition that the Greenfield site is so new that the underlying assumptions have yet to be fully developed. Alternatively it could just be the fact that the Greenfield site only had 43 staff who still felt involved in the honeymoon period of this new site. As the Greenfield site is still growing in size the new members sense a feeling of success and therefore start believing in the new site's philosophies. This is similar with Hatch's (1993) proposition that organisational success enables the founder's beliefs and values to undergo cognitive transformation into assumptions.

Clearly the Greenfield staff have the opportunity to be influenced by their immediate managers, who in turn have been carefully selected against predetermined criteria set primarily by Brownfield management. Using Schein's (1992) analogy, each manager within the Greenfield site could in effect be viewed as the "founder" of their respective business units. They are the ones that the staff inter- 
act and associate with. They are the ones that ensure the twenty three page trust document is implemented in the spirit in which it was intended and accepted by staff.

This could leave the Greenfield site in a very vulnerable position if there was a change in support for the 'trust' document by either staff or management. The organisational culture may not have matured to such an extent that it would last beyond the immediate management personnel. The willingness shown in the James Wattie's era to never dismiss anyone for poor performance, has not followed through to the Heinz era. Indeed the current Operations Manager said:

You are only as good as your last performance. There is no history to your career. What you have done in the past is irrelevant. As soon as the result is not delivered, management will exit the business and a new set of managers will come in. The signal is clear - Deliver or go!

If there were changes to personnel, the new managers may not be as intimately aware of, and committed to, the key ingredients of the culture management process and be more susceptible to pressure to interpret clauses in the interests of gaining greater productivity and efficiency for the company. The Operations Manager conceded that he felt the Greenfield culture had not yet reached the stage of not requiring continual attention.

\section{The longevity of the current Greenfield style will be as long as it can deliver a result. As soon as the result is not delivered, the trust document will go to the wall. Management will then exit.....The difficulty you have got is whether you have it embedded long enough for it to become a way of life.}

Furthermore, as the organisation increases in size the possibility of making selection mistakes also increases and new staff may elect to take advantage of a more 'open' industrial document. These scenarios could possibly increase the pressure to start 'dotting the i's crossing the t's' in the twenty three page trust document and therefore signal the start of a less 'trusting' document and birth of a more complex and prescriptive industrial document. To date this has not happened and the current management team still have a passion for the philosophies and values contained in the Tomoana Employment Contract. 'So long as the managers have a passion for it the people will trust you on how it is going to work' (Site Management, 1999).

The next logical step in the process would be for other plants within the Heinz Wattie's group to use the Greenfield practices to influence change within the Brownfield site. But, interestingly, the Operations Manager concedes that while;

Tomoana is being used at Hastings as a strategic change weapon it is not elsewhere within the business. People elsewhere in the organisation are cynical as to whether the experiment is going to work or not.

Could it be that these comments reinforce the true underlying assumptions of profit within the Heinz Group and provided that you achieve the targets you'll escape the attention of the spot light? As local management continue to achieve their predetermined targets they will be free to continue with the next stage of the experiment. Whether Thompson's (1990) proposition holds true that the next stage will be more difficult as the managers are attempting to change an existing culture instead of creating a new culture would be the obvious extension of the case study for further research.

Another dimension discussed in the literature was the ability of management, during the process of establishing a Greenfield site, to dilute the penetration of union involvement.

\section{At Tomoana we don't have union involve- ment. While we have union members they (the union) are not party to the contract.}

Although the researcher was unable to substantiate the validity of this comment, anecdotal evidence was obtained to suggest that staff do have 'trust' in the Tomoana Employment Contract and rarely see the need to seek third party assistance. However the Brownfield employment practices when compared to the practices within the Greenfield site are seen by management as 'draconian.' This additional dimension of union power and the need for significant change to the employment contract may also be a significant hurdle to overcome when introducing some of the Greenfield practices within the Brownfield site. The recently elected Labour / Alliance Coalition Government intends to repeal the Employment Contracts Act 1991 and introduce significantly different Employment Relations legislation in August 2000. They have a clear agenda of promoting unionism which could profoundly impact on the Greenfield site and further entrench historical Brownfield practices.

\section{Future Research}

Clearly the findings of this study have supported the proposition that there was a difference between the culture within the case study's Brownfield and Greenfield sites. The obvious extension of the study is to investigate whether the alternative culture has contributed to the bottom line performance of the organisation. On the surface it would appear that it has, but a more thorough investigation needs to be conducted. It may also be of interest to research whether the new culture has benefited the staff as well as the company, to confirm or refute the suggestion in the literature that the management of culture can be perceived to be manipulation of the employees purely for the company's ends. Further research would validate or contradict the view of management in the case study, that staff have benefited from the Greenfield culture in terms of increased 
job security, opportunities for additional earnings and participation in decision making.

The ultimate question emerging at the conclusion of this study, is how long will it last? Will pressure be exerted to formalise and 'tighten' the Greenfield trust document as the organisation increases in size? Will the intended change in New Zealand's employment law effect the level of union involvement? Furthermore as the Greenfield evolves through the business lifecycle and the rapid expansion reaches a plateau, can the commitment to the Team Tomoana Concept be sustained?

\section{Notes}

1 The hours bank is a system for debiting and crediting hours below or above the weekly norm. Credits are periodically paid out to individual staff members.

2 Developers and users of the $\mathrm{OCI}^{\circ}$ are inconsistent in reporting the three cultures and twelve cultural norms. For consistency, Constructive, Passive-Defensive and Aggressive-Defensive as titles will be referred to as cultural styles while achievement, self-actualisation, humanistic-encouragement, affiliative, approval, conventional, dependent, avoidance, oppositional, power, competitive and perfectionistic will be referred to as cultural norms.

Refer to Cooke, (1988) for a full description of each of the culture norms.

An average rating was calculated for each of the 96 items that comprise the OCI. The scores in the table represent the aggregated averages for each cluster, and across all items.

Paul Hursthouse is a Senior Lecturer within the Faculty of Business Studies, Eastern Institute of Technology, New Zealand. His current interest is investigating the effect various Human Resource strategies have on both staff and the organisation's performance.

Darl Kolb a Senior Lecturer in Organisational Change and Development at the University of Auckland Business School. His research includes concept mapping organisational cultures and technology uptake in small manufacturing and new economy firms.

Submitted for publication for the Special Issue of Personnel Review on Managing Human Resources on Greenfield Sites. The issue will appear in mid 2001.

\section{References}

Alvesson, M. and Berg, P.O. (1992). Corporate Culture and Symbolism: An Overview. Berlin: Walter de Gruyter.

Baird, M. (1999), Strategic Change at Greenfield and Brownfield Sites: A Study of Employee Commitment at the Workplace Level. Unpublished Phd In Progress, University of Sydney.

Batstone, E., Ferner, A. and Terry, M. (1984), Consent and Efficiency. Oxford: Blackwell.

Bolman, L. and Deal, T. (1991), Reframing Organisations: Artistry, Choice and Leadership. San Francisco: Jossey-Bass Publishers.

Cappelli, P. (1985), Competitive Pressures and Labour Relations in the Airline Industry, Industrial Relations, 22 ( 3) 316-338.

Casey, C. (1999), Come, Join our Family:Discipline and Integration in Corporate Organisational Culture, Human Relations, 52 (2) 155-178.

Clark, J. (1995), Managing Innovation and Change. London: Sage.

Conly (1984) Watties - The First 50 Years.

Cooke, R. A. and Lafferty, J. C. (1983), Organisational Culture Inventory, Human Synergistics, Plymouth, MI.

Cooke, R. A. and Rousseau, D. M. (1988), Behavioural Norms and Expectations: A Quantitative Approach to the Assessment of Organisational Culture, Group and Organisational Studies, 13 (3) 245-273.

Cooke, R. A. and Szumal, J. L. (1993), Measuring Normative Beliefs and Shared Behavioural Expectations in Organisations: The Reliability and Validity of Organisational Culture Inventory, Psychological Reports, ( 72) 1299-1330.

Crane, D. (Ed.) (1994), The Sociology of Culture: Emerging Theoretical Perspectives. Cambridge, Blackwell.

Douglas, R. (1990), Speech - New Zealand Finance Minister to Australian Graduate School of Management, $20^{\text {th }}$ July. Unpublished.

Foulkes, F. (1980), Personnel Policies in Large Non Union Companies, HJ:Prentice-Hall, Englewood Cliffs.

Frost, P. Moore, L., Louis, M. Lundberg, C. and Martin, J. (Eds.) (1985), Organisational Culture, Beverly Hills : C.A:Sage.

Gagliardi, P. (1986) The Creation and Change of Organi- 
sational Cultures: A Conceptual Framework, Organisational Studies, Vol. 7, No. 2, pp. 117-134.

Geare, A. (1991), "Employment Contracts Bill" Management Department, Otago University, Dunedin.

\section{Goodman, J., Armstrong, G., Davis, J. and Wagner, A.} (1977), Rule Making and Industrial Peace, London: Croom Helm.

Gospel, H. and Littler, C. (1983), Managerial Strategies and Industrial Relations, Heinemann, London.

Guest, D. and Rosenthal, P. (1993), Industrial Relations in Greenfield Sites, (Discussion Paper 127): Centre for Economic Performance.

Hatch, M. J. (1993), The Dynamics of Organisational Culture, Academy of Management Review, 18 (4) 657-693.

Heinz Wattie's (1998), Employee Resource Kit/Handbook, Hastings: Heinz Wattie's.

Hursthouse, P. (1999), Greenfields - Fertile Ground For Cultivating Culture : The Heinz Wattie's Case MCom Thesis, Depart of Management and Employment Relations, University of Auckland.

Irving, D. and Inkson, K. (1998) It Must Be Wattie's!, Auckland: David Bateman Ltd.

Kochan, T., McKersie, R. and Katx, H. (1985) US Industrial Relations in Transition: A Summary Report, In Proceedings of the 33rd Annual Meeting, (Ed, B, I. D.) Industrial Relations Research Association, Madison, Wisconson, pp. 265-274.

Krefting, L. A. and Frost, P. J. (1985), Untangling the Webs, Surfing Waves, and Wildcatting: A Multiple-Metaphor Prespective on Managing Culture. In Frost et. al (Ed.), Organisation Culture . Beverly Hills: Sage

Leopold, J. and Hallier, J. (1997), Start-up and Ageing in Greenfield Sites, Human Resource Management Journal, 7 (2) $72-89$.

Marchington, M. (1990), "Analysing the Links Between Product Markets and the Management of Employee Relations", Journal of Management Studies, Vol. 15, No. 2, pp.111-128.

Marchington, M. and Loveridge, R. (1983), Non-participation: The Management View? Joumal of Management Studies, 16 ( 2) 171-84.

McAndrew, I. and Hursthouse, P. (1990), Southern Employers on Enterprise Bargaining, New Zealand Journal of Industrial Relations, 15 (2) 117-128.
New Zealand Business Roundtable. (1989), Review and Operation of the Labour Relations Act in the 1988/ 99 Wage Round, Wellington.

Ott, J. (1989), The Organisational Culture Perspective, C A:Brooks and Cole, Pacific Grove.

Peters, T. J. and Waterman, R. H. (1982), In Search of Excellence: Lessons from America's Best-Run Companies, Harper and Row, New York.

Pettigrew, A. M. (1979), On Studying Organisational Cultures, Administrative Science Quarterly, 24, 570-581.

Purcell, J. and Grey, A. (1986), Corporate Personnel Departments and the Management of Industrial Relations: Two Case Studies in Ambiguity, Journal of Management Studies, 23, (2) 205-223.

Siehl, C. and Martin, J. (1988), Measuring organisational culture: Mixing qualitative and quantitative methods. Jones, M. O., Moore, M. D. and Snyder, R. C. (eds) Inside Organisations Newbury Park, CA: Sage.

Schein, E. H. (1992), Organisational Culture and Leadership (2nd ed), San Franscisco: Jossey-Bass.

Singer, A. (1996), Wattie's on the Move. Business to Business, 2 ,19-42.

Site Management (1999), Interviews with Senior Managers - Not Appropriate to Identify Individuals.

Thompson, K., \& Luthans, F. (1990). Organisational Culture: A Behavioural Perspective. B. Schneider (ed.), Organisational Climate and Culture (pp. 319344). San Francisco: Jossey-Bass

Xenikou, A. and Furnham, A. (1996) A Correlational and Factor Analytic Study of Four Questionnaire Measures of Organisational Culture, Human Relations, 49 (3) 349-371.

\section{Authors}

Paul Hursthouse

Senior Lecturer, Faculty of Business Studies

Eastern Institute of Technology

Private Bag 1201

Taradale

phursthouse@eit.ac.nz

\section{Darl Kolb}

Senior Lecturer, School of Business and Economics, University of Auckland

Private Bag 92019

Auckland

d.kolb@auckland.ac.nz 